\title{
Regional Differences in the Amino Acid Sequences of Fasciola hepatica Cathepsin L2 From a Turkish Isolate
}

\author{
Serpil Başpınar ${ }^{1}$, Venhar Çelik², Dilek Turgut Balık³ ${ }^{3}$ Mustafa Kaplan ${ }^{4}$ \\ ${ }^{1}$ Vocational School of Health Services, Fırat University, Elazı̆̆, Turkey \\ ${ }^{2}$ Department of Biology, Faculty of Medicine, Fırat University, Elazığ, Turkey \\ ${ }^{3}$ Department of Bioengineering, Yıldız Technical University, İstanbul, Turkey \\ ${ }^{4}$ Department of Medical Parasitology, Faculty of Medicine, Firat University, Elazı̆̆, Turkey
}

\section{ABSTRACT}

Objective: This study describes cloning and sequence analysis of the gene coding for the cathepsin L2 gene from a F. hepatica isolate from Turkey.

Methods: The adult form of $F$. hepatica was collected from the infected cattle liver and cDNA was obtained following total RNA isolation. After amplification of the gene by PCR, ligation and transformation was performed. Finally, DNA sequencing and phylogenetic analysis were performed.

Results: The gene consists of an open reading frame of 981 nucleotides corresponding for 327 amino acids. There are five amino acid positions where Firat F. hepatica cathepsin L2 differs from the F. hepatica cathepsin L2 Dublin strain. This sequence was the first cathepsin L2 gene from a Turkey isolate and the second cathepsin L2 sequence entered into the database. A comparative amino acid sequence analysis indicated that there is about $99 \%$ homology with the F. hepatica cathepsin L2 reported in the literature, $98 \%$ homology with the F. hepatica cathepsin L-like protease, and $85 \%$ homology with the F. hepatica cathepsin L1 isolated in the Elazığ region at the nucleotide level.

Conclusion: The amino acid differences between sequences could be evaluated for further immunization and diagnosis studies.

Key Words: Fasciola hepatica, cathepsin L2, nucleotide, amino acid sequence

Received: 13.11.2009 Accepted: 17.05.2010

\section{Introduction}

Fasciola hepatica is a liver trematode, which is a member of the family Fasciolidae under the subclass Digenea, and causes fasciolosis in humans and animals. While fasciolosis is more widespread in countries breeding cattle and sheep, it is a common problem in both developed and developing countries $(1,2)$. Although fasciolosis was traditionally regarded as a world-wide disease of livestock, the disease has recently emerged as an important human zoonosis in South America, Egypt, Iran, and Vietnam (3). Its medical importance has also increased in Turkey compared to the previous years $(4,5)$.

Although the history, clinical symptoms and laboratory findings may suggest fasciolosis in a patient, these only support the diagnosis. Instead, coprologic methods, serologic tests, radiologic imaging techniques, and molecular biology techniques are used in diagnosis (6-9). Demonstration of Fasciola hepatica or its eggs provides a definite diagnosis. However, examination of feces is frequently inadequate for diagnosis. This is because eggs are not detected in the stool during the acute phase of infection and ectopic settling $(6,10)$. For this reason, serologic methods are frequently used in the diagnosis of particularly acute fasciolosis. ELISA, IHA, counter-electrophoresis, and Western blot are the preferred tests. As cross reactions are rare in these tests, E/S antigens (excretion-secretion) or partially purified parasite products are used. Cysteine proteinases, which are the most frequently found E/S antigens, are secreted by both the adult and young forms, and are quite antigenic in animals and humans. For this reason, they are valuable in diagnosis (8). Purified and recombinant antigens have begun to be used in recent years (11-13).

Cathepsin L1 and L2, are predominant in adult F. hepatica gut contents and excretion/ secretion products (14). The adult stage of $F$. hepatica secretes several cysteine proteases and the cathepsin L-like proteinases are proposed to be involved in activities such as invasion of tissues, feeding, immune evasion, or egg shell formation (14). Cathepsin L1 and L2 proteins are potential molecules to be used in diagnostic methods $(8,11,12)$ and in immunization studies for protection purpose (15-19) as they are specific to F. hepatica.

Genetic variations are widespread in parasite populations. The understanding of the parasite life cycle, transmission, study of population biology, epidemiology, as well as genetic variation in parasite populations is important for the control and effective prevention of parasitic diseases in humans and animals. Thus, the accurate analysis of genetic variation in parasites has important implications (20). Additionally, in order to eliminate or minimize the impact of these parasites and 
to be used in diagnostic methods and immunization studies, it is also important to understand the genetic diversity of the liver fluke populations and the relationship between parasite and host at regional bases (21). It is shown that there are regional differences in Cat L1 of F. hepatica (22) and these differences in amino acid residues appear to affect immunogenity of the protein involved. Cornelissen and collaborates (23) proved with synthetic peptides that the difference in only three amino acides results in major differences in immunodiagnostic potential. These differences in the amino acid residues may also affect the serological diagnostic tests to show the same specificity and sensitivity at every region. Therefore, we suggest that local studies are of importance in the selection of antigens for serological diagnostic tests.

This study was carried out to determine regional differences in the amino acid sequences of Fasciola hepatica secreted cathepsin L2 in an isolate from Turkey.

\section{Material and Methods}

\section{Parasite}

The adult forms of Fasciola hepatica were collected from the infected cattle liver. The parasitee were washed 5 or 6 times with physiologic saline and transferred into the phosphate buffered saline (PBS). They were stored in PBS at $37^{\circ} \mathrm{C}$ until a total RNA isolation process.

\section{Vector, Bacterial Strain and Growth Media}

pGEM-T easy vector system (Promega, U.K.) was used for cloning of the PCR product. The host bacterial strain used for transformation was E. coli JM109 for cloning. Ampicillin was used in LB agar for the selection and growth of transformants where necessary. Bacterial cells were grown on minimal agar and made competent using $\mathrm{CaCl}_{2}$ solution (24).

\section{Isolation of Total RNA}

All steps of total RNA isolation were performed under sterilised conditions. 3 adult F. hepatica stored in PBS as live parasites were weighed and washed with PBS a few times. These were then cut into small pieces using a blade and put into the centrifuge tubes. $1 \mathrm{ml}$ of TRI reagent (Sigma Chemical Co. St. Louis, MO, ABD) was added to each $50-100 \mathrm{mg}$ of the parasite weight and centrifuged at $13.500 \mathrm{rpm}$, for 10 minutes at $4^{\circ} \mathrm{C}$. The upper phase was transferred into a clean tube. $0.2 \mathrm{ml}$ of chloroform was added onto this sample per $\mathrm{ml}$ of TRI reagent used in the previous steps. It was then mixed gently for $15 \mathrm{sec}$ onds prior to centrifugation at $13.500 \mathrm{rpm}$, for 15 minutes at $4{ }^{\circ} \mathrm{C}$. The upper phase that includes RNA was transferred into a clean tube. $0.5 \mathrm{ml}$ isopropanol was added per $\mathrm{ml}$ of TRI reagent used in the previous steps, incubated at room temperature for 10 minutes and centrifuged at $13.500 \mathrm{rpm}$ for 10 minutes at $4{ }^{\circ} \mathrm{C}$. The supernatant was removed and $1 \mathrm{ml}$ of $70 \%$ cold ethanol was added onto the pellet per $\mathrm{ml}$ of TRI reagent used in the previous steps and centrifuged immediately at $13.500 \mathrm{rpm}$, for 5 minutes at $4^{\circ} \mathrm{C}$. Supernatant was removed following the centrifugation. RNA was air dried and dissolved in $100 \mu \mathrm{l}$ of $\mathrm{dH}_{2} \mathrm{O}$ containing $1 \mu$ RNasin (Promega Co, Madison, WI, ABD). RNA was stored at $-80^{\circ} \mathrm{C}$ until needed.

\section{Obtaining cDNA by Reverse Transcription}

Two specific oligonucleotide primers complementary to the forward and reverse strands of the $F$. hepatica cathepsin L2 gene were designed using the gene sequence of $F$. hepatica cathepsin L2 (Genbank Accession No: U62289) for the amplification of the gene by RT-PCR. These oligonucleotide primers were called P1 (GGCTCGAGATGCGGTGCTTCGTA and P2 (GGGTCGACTCACGGAAATCGTGCC) and synthesized by The Midland Certified Reagent Co, Texas, ABD.

$\mathrm{P} 1$ and $\mathrm{P} 2$ oligonucleotide primers were diluted to $20 \mathrm{pmol}$ prior to the reverse transcription process. $2.5 \mu \mathrm{l}$ of each primer and $5 \mu \mathrm{l}$ of RNA were transferred into an Eppendorf tube and incubated at $70^{\circ} \mathrm{C}$ for 5 minutes. This was then cooled to the room temperature and mixed with $1 \mu$ M M-MLVRT (MoloneyMurine Leukemiea Virüs Reverse Transcriptase, Promega Co Madison, WI, ABD), $5 \mu$ l Reverse Transcriptase Buffer (Promega Co Madison, WI, ABD), $0.7 \mu \mathrm{l}$ RNasin (Promega Co Madison, $\mathrm{WI}, \mathrm{ABD})$, and $4 \mu \mathrm{l}$ of dNTP mixture $(10 \mu \mathrm{l}$ of each $10 \mathrm{mM}$ dNTPs and $10 \mu \mathrm{l}$ of $\mathrm{H}_{2} \mathrm{O}$ ) (Promega Co Madison, WI, ABD). This mixture was incubated at $37^{\circ} \mathrm{C}$ for 1 hour to obtain the cDNA.

Amplification of the F. hepatica Cathepsin L2 Gene by PCR

The enzyme ExTaq DNA Polymerase form Takara was used to amplify the DNA. This polymerase often adds a single deoxyadenosine, in a template independent fashion, to the 3 '-end of the amplified fragments, which allows these products to be used for T vector cloning (Promega, U. K.). The reaction mixture contained, $5 \mu \mathrm{l}$ of buffer containing $\mathrm{MgCl}_{2}$ (supplied with the enzyme), $4 \mu$ l of dNTPs (stock at $2.5 \mathrm{mM}$ ), $2 \mu \mathrm{l}$ of each oligonucleotide primers (stock $20 \mathrm{pmol}$ ), $5 \mu$ l of cDNA from F. hepatica, $1 \mu$ l of Ex Taq DNA Polymerase (stock $5 \mathrm{U} / \mu \mathrm{l}$ ) and $\mathrm{dH}_{2} \mathrm{O}$ to a final volume of $50 \mu \mathrm{l}$. DNA was first incubated at $95^{\circ} \mathrm{C}$ for 2 minutes and then denatured at $94^{\circ} \mathrm{C}$ for 1 minute, annealed at $44^{\circ} \mathrm{C}$ for 2 minutes and extended at $72^{\circ} \mathrm{C}$ for 2 minutes for 35 cycles. This was followed by a 10 minutes final extension at $72^{\circ} \mathrm{C}$.

Analysis of PCR product on a $1 \%$ agarose gel revealed the presence of a band at about the right size. This band was extracted from the gel using Promega's Wizard SV Gel and PCR Clean-Up System (25).

\section{Ligation and Transformation}

Both ligation and transformation were performed according to the suppliers instructions (Promega, U. K.).

\section{DNA Sequencing}

Inserts were initially checked by colony PCR using the P1 and P2 oligonucleotide primers and obtained expected size PCR bands, indicating that there might be positives. Plasmid DNA was then prepared using Wizard Plus SV Minipreps DNA Purification System (Promega U.K.) and submitted for sequencing from both directions.

\section{Phylogenetic Analysis}

Sequence data were analysed using Genetix-Mac, and EMBL/GenBank database searches were performed with the FASTA program. The alignment of sequences was carried out using the CLUSTAL W program (26) available over the World Wide Web (http://www.ddbj.nig.ac.jp/E-mail/homology.html). 


\section{Results}

Image of the PCR-amplified F. hepatica cathepsin L2 gene in $1 \%$ ethidium bromide-stained gel is given in Figure 1. After cloning of this $981 \mathrm{bp}$ product into the pGEM-T vector, the correct sequence was confirmed by sequencing.

Figure 2 shows the cDNA sequence of cathepsin L2 acquired by sequence analysis of the recombinant vector pGEMT (GenBank Accession No: EF611824). Once the sequence was confirmed by sequencing, the gene was then called Firat F. hepatica cathepsin L2.

Figure 3 presents a comparative amino acid sequence analysis between Fasciola hepatica secreted cathepsin L2 that cloned in the present study and some other members of the family Fasciolidae, and figure 4 shows a family tree of Cathepsin L2.

\section{Discussion}

Nucleotide and amino acid sequence of cathepsin L2 gene was detected in our study at cDNA and recombinant vector levels. The nucleotide sequence of cathepsin L2 detected in our study is the second F. hepatica cathepsin L2 nucleotide sequence reported in the literature, and shows $99 \%$ homology with the $F$. hepatica cathepsin $L 2$ reported by Dowd and collaborates (27) (GenBank Accession No: U62289). The open reading frame of $F$. hepatica cathepsin $L 2$ gene cloned in this study (Firat F. hepatica cathepsin L2) consists of 981 base pairs corresponding to 327 amino acids. Amino acid difference was observed at 5 positions compared to the Dublin F. hepatica cathepsin L2 (Figure 5).

Firat $F$. hepatica cathepsin L2 was also detected to have 98\% homology with the F. hepatica cathepsin L-like protease (GenBank Accession No: Z22764) reported by Heussler and Dobbelaere (28) and $85 \%$ homology with the F. hepatica cathepsin L1 (GenBank Accession No: AY573569) isolated in Elazig region (29).

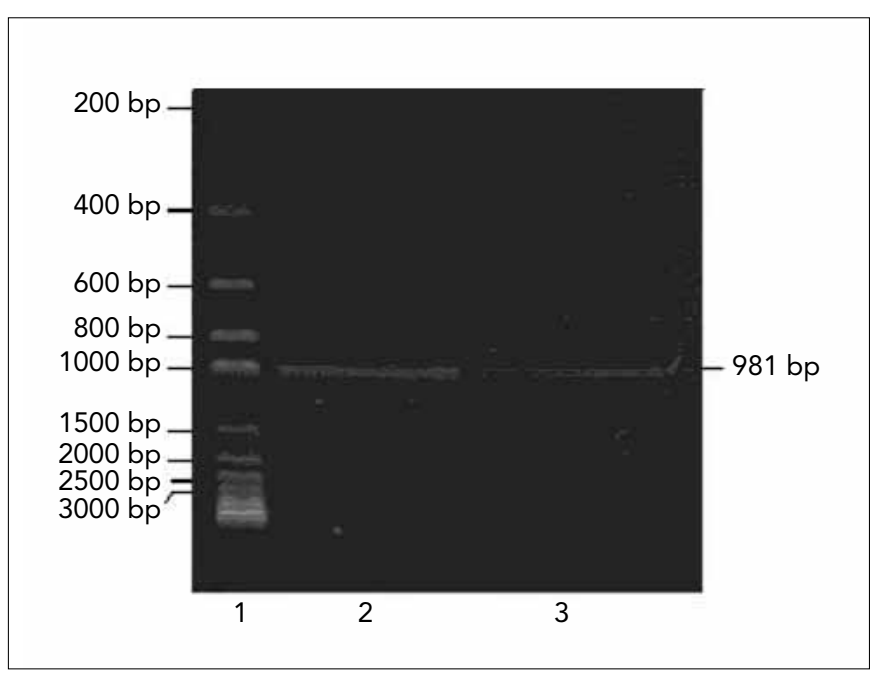

Figure 1. Image of the PCR-amplified F. hepatica cathepsin L2 gene in 1\% ethidium bromide-stained gel. Line 1: HyperLadder I Marker; Line 2 and 3: Cathepsin L2

ATGCGGTGCTTCGTATTAGCCGTCCTCACGGTCGGAGTGTTCGCCTCGAATGACGATTTO TACGCCACGAAGCATAATCGGCAGGAGTGCCAGCCTCACAAGCGGAGCTTACTGCTAAAC

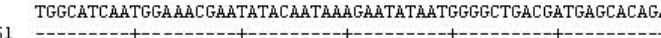

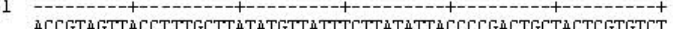

aa:

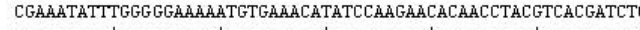

GCTTTATAACC CCTTTTTACACTTTGTATAGGTCTGTTGG

aa:

181 GGCCTCGTCACCTACAAGTTGGGATTGAäCAäTTCACTGaTTTGäCATTCGAGGÄATTC CCGGÄGCAGTGGATGTTCAACCCTAACTTGGTTAAGTGACTAAÄCTGTAÄGCTCCTTAAG

241 AaGGCCAAÄTÀTC TẢATAGÄAATCCCẢCGCTCGTCTGäGTTACTCTCACGCGGTATCCC 41 TTCCGGTTAMTAGATTATCTTTAGGGTGCGAGCAGCCTCAATAAGAGTGCGCCATAGGGC aa: LysAlaLysTyrL euIleGluIleProArgSerSerGluLeuLeuserArgGlyIlePro

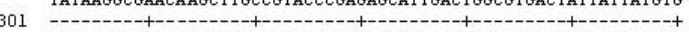
ATÁTTCCGCTTGTTCGAACGGCATGGGCTCTCGTAaCTGACCGCACTGATAäTÁATACAC TYrLYsẢlaAsnL YsLeuẢlaVal ProGluserIl eẢspTrpÅrgảspTyrTyrTYrVal

ACTGAGGTGAAAG ATCAGGGACAATGTGGTTCCTGTTGGCTTTCTCAACAACCGGTGC

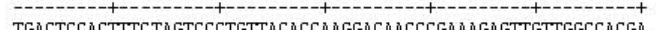
ThrGluValLYsÀ spGlnGlYGlnCYsGlYSerCYsTrpÄlaPheSerThrThrGlYẢla GTGGAGGGACAGTTTAGGAAGAACGAAAGAGCTAGTGCTTCATTCTCTGAGCAACAACT CACCTCCCTGTCAAATCCTTCTTGCTTTCTCGATCACGAMGTAäaGäTCGTTGTTGAC aa: ValGluGlyGlnPheẢrgLYsẢsnGluẢrgẢlaSerẢlaSerPheSerGluGlnGlnLeu

CACT ValÄspCysThrảrgảspPheGlYẢSnTYrGlYCYSGLYGlYGlYTYrMetGluẢsnẢ

TATGAATATTTGAAACACAACGGATTGGAAACTGAGTCCTATTATCCATACCAGGCTGTO -----------------------aa: TYrGluTYrLeuL YsHisAsnGlyLeuGluThrGluSerTyrTyrProTyrGlnAlaVa

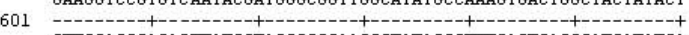
CTTCCAGGCACAGTTATGCTACCCGCCAACCGTATACGGTTTCACTGäCGATGATATGA GluGlYProCysG InTYrAspGlYÄrgLeuAl aTYrAl LLYsValThrGlYTYrTYrThr

661 GTGCATTCTGGCGATGAGATAGAATTAAAGAATTTGGTCGGTACCGAAGGACCTGCGGCC

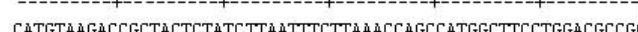
ValHisSerGlYAspGluIleGluLeuLYsAsnLeuValGlYThrGluGlYProAlaAla GTCGCTTTGGATGCGGATTCTGACTTCATGATGTACCAGAGTGGTATTTATCAGAGCCAA CÄGCGÄÄCCTÁCGCCTÄAGACTGÄGTACTACATGGTCTCACCATAAATÄGTCTCGGTT ValÄlaLeuẢspẢlaẢspSerẢspPheMe tMetTYrGInSerGlYIleTYrGlnSerGln

ACTTGTTTACCGGATCGCTTGACTCATGCAGTCTTGGCTGTCGGTTATGGATCACAAGAT

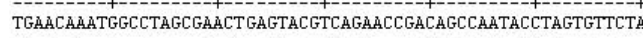
ThrCYsLeuProAspẢrgLeuThrHisẢlaValLeuẢlaValGlYTyrGlySerGlnẢsp

$841-10$ GlYThrAspTYrTrpIleValL YsAsnSerTrpGlYThrTrpTrpGlYGluAspGIYTYr

TTCGGTTTGCCAGGAACCGÄGGTAATATGTGTGGAATTGCTTCTCTGGCCAGTGTCCC

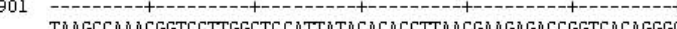
TAAACCAAAACGGTC IleẢrgPheẢlaẢrgẢsnÄrgGlYAsnMe tCYsGlYIleAllaSerLeuẢlaSerValPro

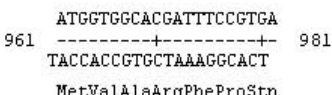

Figure 2. The nucleotide and aminoacid sequence of Fasciola hepatica secreted cathepsin L2 (FheCL2). Gene Bank Accession No: EF611824 


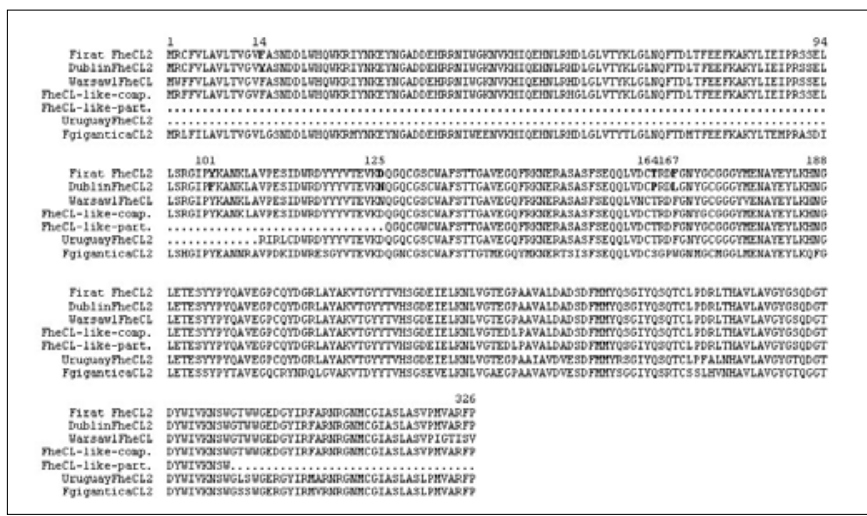

Figure 3. The comparative amino acid sequences of Fasciola hepatica secreted cathepsin L2 and other members of the family Fasciolidae. Firat FheCL2: Fasciola hepatica secreted cathepsin L2 (Strain Firat) (GenBank Accession No: EF611824), Dublin FheCL2: Fasciola hepatica secreted cathepsin L2 (Strain Dublin) (GenBank Accession No: U62289), Warsaw1FheCL: Fasciola hepatica isolate Warsaw 1 cathepsin L mRNA (GenBank Accession No: EF407948), FheCL-like-comp.: Fasciola hepatica cathepsin L-like protease mRNA complete cds. (GenBank Accession No: Z22765), FheCL-like-part.: Fasciola hepatica cathepsin L-like protease mRNA partial cds. (GenBank Accession No: Z22764), UruguayFheCL2: Fasciola hepatica cathepsin L2 mRNA partial cds. (GenBank Accession No: DQ533985), FgiganticaCL2: Fasciola gigantica cathepsin L2 (GenBank Accession No: AF510856). The amino acid differences between Firat FheCL2 and Dublin FheCL2 are shown in bold

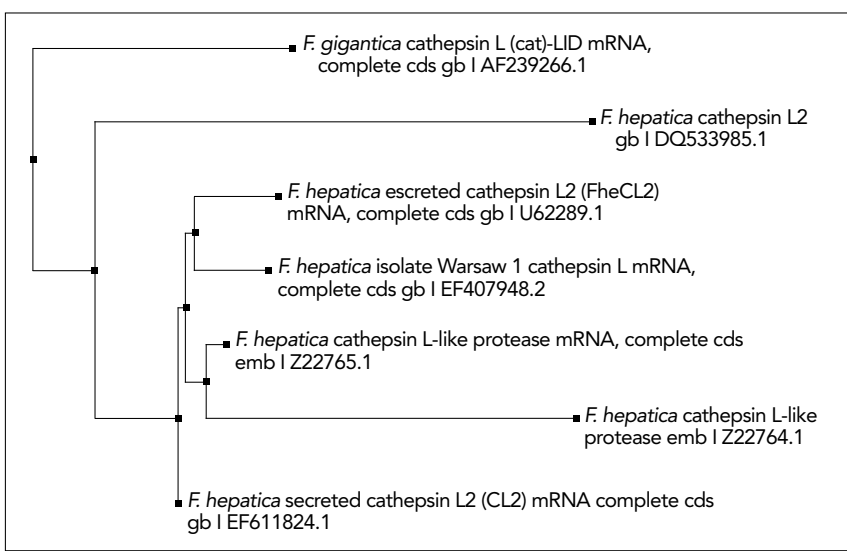

Figure 4. Family tree of cathepsin L2. Firat FheCL2: Fasciola hepatica secreted cathepsin L2 (Strain Firat) (GenBank Accession No: EF611824), DublinFheCL2: Fasciola hepatica secreted cathepsin L2 (Strain Dublin) (GenBank Accession No: U62289), Warsaw1FheCL: Fasciola hepatica isolate Warsaw 1 cathepsin L mRNA (GenBank Accession No: EF407948), FheCL-like-comp.: Fasciola hepatica cathepsin L-like protease mRNA complete cds. (GenBank Accession No: Z22765), FheCL-like-part.: Fasciola hepatica cathepsin L-like protease mRNA partial cds. (GenBank Accession No: Z22764), Uruguay FheCL2: Fasciola hepatica cathepsin L2 mRNA partial cds. (GenBank Accession No: DQ533985), FgiganticaCL2: Fasciola gigantica cathepsin L2 (GenBank Accession No: AF510856)
Parasite populations showed frequent genetic variations. It is docemented that there are regional differences in CatL1 of $F$. hepatica (22). However, there is no adequate information for cathepsin L2. The effective control of parasitic diseases requires the understanding of the parasite's life cycle, transmission, epidemiology as well as genetic variation in Fasciola spp. populations. Therefore, the accurate analysis of genetic variation in parasites has important implications (20).

It has been reported that studies with cathepsin L1 in fasciolosis diagnosis revealed no cross reactions, and that the specificity and sensitivity was high in the ELISA method where it is used as an antigen (8). However, in the literature, there are no adequate studies on the place of cathepsin L2 in the diagnosis of fasciolosis. We believe it can be suggested that the recognition of regional differences in cathepsin L2 of the liver fluke populations is important in selection as an antigen for use in diagnostic methods.

Another significant issue related to fasciolosis is the loss of yield, particularly in stock animals, and the economic losses due to animal deaths. It is emphasized in the studies on the prevalence of fasciolosis and the economic loss rates that it may lead to high economic losses in the countries where it is common, and also in our country; and that an urgent and efficient protection strategy should be developed (30). However, there are no adequate numbers of immunization studies yet. There is no commercial vaccine available against fasciolosis. However, studies on developing such a vaccine are pending. Various molecules such as cathepsin L1, cathepsin L2, leucine amino-peptidase (LAP), glutathione S-Transferase (GST), hemoglobin, fatty acid-binding protein (FABP), and paromyosin are tested as vaccines against $F$. hepatica (15-19).

Testing of cathepsin L1, as an E/S product cysteine protease of Fasciola hepatica, as a vaccine on its own and together with cathepsin L2 gave promising results (31). A protection rate of $33-69 \%$ was reported in various studies. Furthermore, egg shedding was also reported to be reduced by $40-71 \%(15,16)$. These results, displaying a scene far from complete protection, led to new searches, and brought the DNA vaccines into consideration $(17,19)$. In a study where $50 \mu \mathrm{g}$ single vaccine with cDNA coding the cathepsin L1 gene of $F$. hepatica was used, the protectivity of the vaccine was reported to be $74 \%$ in female rats, and $100 \%$ in male rats (19). However, there is no study on cathepsin L2 cDNA vaccine yet. Further studies are needed on DNA vaccines, which is a quite new area of research. Using cathepsin L2 cDNA obtained in the present study could increase present knowledge in the design of new DNA vaccines against $F$. hepatica. However, it is shown that there are regional differences in the CatL1 of $F$. hepatica (22). Importantly, these differences in amino acid residues appear to affect immunogenity of the protein involved. Cornelissen and collaborates (23) proved with synthetic amino acid antigens that a difference in only three amino acides results in major differences in the mmunodiagnostic potential. Therefore, consideration of the regional differences in cathepsin L2 of the liver fluke populations in selection of the optimal immunogenic protein or the DNA fragment for study of vaccination may be necessary.

As a result, the cDNA coding the F. hepatica cathepsin L2 gene was cloned and transformed to the competent JM109 
E. coli cell in this study. The nucleotide sequence and amino acid pattern of the $F$. hepatica cathepsin L2 was determined and presented as the second such sequence in the database. The importance of the five amino acids difference in Firat F. hepatica cathepsin L2 compared to the Dublin F. hepatica cathepsin L2 sequence could be exploited for immunization and diagnostic studies. These studies will be possible with the vector containing the cloned cDNA, or the recombinant cathepsin $\mathrm{L} 2$ protein to be acquired in the further stages of the study.

\section{Acknowledgement}

This study was supported by Firat University Scientific Research Project Unit (FUBAP).

\section{Conflict of Interest}

No conflict of interest was declared by the authors.

\section{References}

1. Bousses SH, Meunier C, Durand P, Renaud F. Dynamics of hostparasite interactions: the example of population biology of the liver fluke (Fasciola hepatica). Microbes Infect 2001;3:841-9. [CrossRef]

2. Mas-Coma S, Bargues MD, Valero MA. Fascioliasis and other plant-borne trematode zoonoses. Int J Parasitol 2005;35:1255-78. [CrossRef]

3. Robinson MW, Dalton JP, Donnelly S. Helminth pathogen cathepsin proteases: it's a family affair. Trends Biochem Sci 2008;33:601-8. [CrossRef]

4. Yilmaz H, Gödekmerdan A. Human fasciolosis in Van province, Turkey. Acta Trop 2004;92:161-2. [CrossRef]

5. Kaya S, Demirci M, Demirel R, Aridogan BC, Ozturk M, Korkmaz $M$. Seroprevalence of fasciolosis and the difference of fasciolosis between rural area and city center in Isparta, Turkey. Saudi Med J 2006;27:1152-6.

6. Garcia LS, Bruckner DA, (editors). Diagnostic Medical Parasitology. (Third Edition). Washington, ASM Press, 1997.

7. Behm CA, Sangster NC. Pathology, Pathophysiology and Clinical Aspects, In: Dalton JP, editor. Fasciolosis. Wallingford, CAB International, 1999

8. Hillyer GV. Immunodiagnosis of human and animal fasciolosis. In: Dalton JP, editor. Fasciolosis. Wallingford, CAB International, 1999.

9. Marcos L, Maco V, Samalvides F, Terashima A, Espinoza JR, Gotuzzo E. Risk factors for Fasciola hepatica infection in children: a case-control study. Trans R Soc Trop Med Hyg 2006;100:158-66. [CrossRef]

10. Makay O, Gurcu B, Caliskan C, Nart D, Tuncyurek M, Korkut M. Ectopic fascioliasis mimicking a colon tumor. World J Gastroenterol 2007;13:2633-5.

11. Strauss W, O'neill SM, Parkinson M, Angles R, Dalton JP. Short report: Diagnosis of human fascioliasis: Detection of anti-cathepsin $\mathrm{L}$ antibodies in blood samples collected on filter paper. Am J Trop Med Hyg 1999;60:746-8.

12. Cornelissen JB, Gaasenbeek CP, Borgsteede FH, Holland WG, Harmsen MM, Boersma W. Early immunodiagnosis of fasciolosis in ruminants using recombinant Fasciola hepatica cathepsin Llike protease. Int J Parasitol 2001;31:728-37. [CrossRef]

13. Kim K, Yang HJ, Chung YB. Usefulness of $8 \mathrm{kDa}$ protein of Fasciola hepatica in diagnosis of fascioliasis. Korean $\mathrm{J}$ Parasitol 2003;41:121-3. [CrossRef]
14. Tort J, Brindley PJ, Knox D, Wolfe KH, Dalton JP. Proteinases and associated genes of parasitic helminths. Adv Parasitol 1999;43:161-6. [CrossRef]

15. Spithill TW, Dalton JP. Progress in Development of Liver Fluke Vaccines. Parasitol Today 1998;14:224-7. [CrossRef]

16. Piacenza L, Acosta D, Basmadjian I, Dalton JP, Carmona C. Vaccination with Cathepsin L Proteinases and with Leucine Aminopeptidase Induces High Levels of Protection against Fascioliasis in Sheep. Infect Immun 1999;67:1954-61.

17. Liljeqvist $S$, Stahl S. Production of recombinant subunit vaccines: protein immunogens, live delivery systems and nucleic acid vaccines. J Biotechnol 1999;73:1-33. [CrossRef]

18. Kofta W, Mieszczanek J, Plucienniczak G, Wedrychowicz H. Successful DNA immunisation of rats against fasciolosis. Vaccine 2000;18:2985-90. [CrossRef]

19. Kofta W, Wedrychowicz H. c-DNA vaccination against parasitic infections: advantages and disadvantages. Vet Parasitol 2001;100:3-12. [CrossRef]

20. Li QY, Dong SJ, Zhang WY, Lin RQ, Wang CR, Qian DX, et al. Sequence-related amplified polymorphism, an effective molecular approach for studying genetic variation in Fasciola spp. of human and animal health significance. Electrophoresis 2009;30:403-9. [CrossRef]

21. Dosay-Akbulut M, Trudgett A, Stanhope M. Understanding genetic diversity of the liver fluke Fasciola hepatica. Z Naturforsch C 2005;60:774-8.

22. Panaccio M, Trudgett A. Molecular Biology. In: Dalton JP, editor. Fasciolosis. Wallingford, CAB International, 1999.

23. Cornelissen JB, Gaasenbeek $C P$, Boersma $W$, Borgsteede $F H$, van Milligen FJ. Use of a pre-selected epitope of cathepsin-L1 in a highly specific peptide-based immunoassay for the diagnosis of Fasciola hepatica infections in cattle. Int J Parasitol 1999;29:685-96. [CrossRef]

24. Sambrook J, Russell DW. Molecular cloning: a laboratory manual 3rd ed. New York: Cold Spring Harbor Laboratory, 2001.

25. Turgut-Balik D, Celik V, Moreton K, Brady L. Overcoming Cloning Problems by Staining Agarose Gels with Crystal Violet Instead of Ethidium Bromide in Lactate Dehydrogenase Gene from Plasmodium vivax and Plasmodium falciparum. Acta Biol Hung 2005;56:3-4. [CrossRef]

26. Thompson JD, Higgins DG, Gibson TJ. Clustal W. Improving the sensitivity of progressive multiple sequence alignment through sequence weighting, position-specific gap penalties and weight matrix choice. Nucleic Acids Res 1994;22:4673-80. [CrossRef]

27. Dowd AJ, Tort J, Roche L, Ryan T, Dalton JP. Isolation of a cDNA encoding Fasciola hepatica cathepsin L2 and functional expression in Saccharomyces cerevisiae. Mol Biochem Parasitol 1997;88:163-74. [CrossRef]

28. Heussler VT, Dobbelaere DA. Cloning of a protease gene family of Fasciola hepatica by the polymerase chain reaction. Mol Biochem Parasitol 1994;64:11-23. [CrossRef]

29. Kuk S, Kaplan M, Ozdarendeli A, Tonbak S, Felek S, Kalkan A. Fasciola hepatica cathepsin L1 from a Turkish isolate is related to Asiatic isolates. Acta Parasitol 2005;50:244-8.

30. Kaplan M, Kuk S, Kalkan A. [Elazığ ELET A.Ş. Kesimhanesinde 1998-2000 Yılları Arasında Kesilen Hayvanlarda Fasciolosis Görülme Sıklığı] Incidence of Fasciolosis in Animals slaughtered Between 1998-2000 in Slaughterhouse of Elazığ ELET Company and Its Economic Significance. Firat medical journal 2002;7:839-42.

31. Spithill TW, Smooker PM, Sexton JL, Bozas E, Morrison CA, Creaney J, Parsons JC. Development of vaccines against Fasciola hepatica. In: Dalton JP, editor. Fasciolosis. Wallingford, CAB International, 1999. 